\title{
PERBEDAAN KEMAMPUAN PEMECAHAN MASALAH MATEMATIS SISWA MELALUI MODELPEMBELAJARANBERBASISMASALAH DENGAN PEMBELAJARAN KONVENSIONAL PADA MATERI RELASI
}

\author{
Safina Umanailo ${ }^{1}$, Hery Suharna ${ }^{2}$, Ahmad Afandi $^{3}$ \\ ${ }^{1,2,3,4}$ FKIP, Universitas Khairun
}

\begin{abstract}
ABSTRAK
Penelitian ini bertujuan untuk mengetahui kemampuan pemecahan masalah matematis siswa melalui model pembelajaran berbasis masalah danperbedaan kemampuan pemecahan masalah matematis siswa melalui model pembelajaran berbasis masalah dengan pembelajaran konvensional. Jenis penelitian yang digunakan adalah jenis penelitian eksperimen tipe pretest-posttest control group design.Sampel dalam penelitian ini adalah 60 siswa yang tersebar dalam dua kelas.Analisis data yang digunakan dalam penelitian ini adalah kualifikasi kemampuan pemecahan masalah matematis siswa, uji normalitas dan homogenitas. Berdasarkan hasil penelitian diperoleh, kualifikasi sangat baik 14 siswa, kualifikasi baik 3 siswa, kualifikasi cukup 2 siswa dan kualifikasi kurang 1 siswa.Dari hasil perhitungan, diperoleh data berdistribusi normal dan tidak homogen, sehingga statistik uji yang digunakan adalah statistik uji parametrik dengan menggunakan uji $\mathrm{t}^{\prime}$, dengan $\mathrm{t}_{\text {hitung }}=2,18$ dan $\mathrm{t}_{\text {tabel }}=2,000$ maka $\mathrm{t}_{\text {hitung }} \geq$ $t_{\text {tabel }}$ atau $2,18 \geq 2,000$ maka $\mathrm{H}_{0}$ ditolak dan $\mathrm{H}_{1}$ diterima yang berarti bahwa terdapat perbedaan kemampuan pemecahan masalah matematis siswa melalui model pembelajaran berbasis masalah (PBM) dengan pembelajaran konvensional pada siswa kelas VIII SMP Negeri 2 Maba.
\end{abstract}

\section{Kata Kunci : PBM, Pembelajaran Konvensional, Kemampuan Pemecahan Masalah Matematis Siswa}

\section{PENDAHULUAN}

Pendidikan sebagai penghubung dua sisi yaitu sisi individu dan nilai. Sisi individu merupakan sisi lain dari nilai sosial, intelektual, dan moral. Nilai adalah norma yang berfungsi sebagai penunjuk dalam mengidentifikasi apa yang diwajibkan, diperbolehkan, dan dilarang. Jadi, pendidikan adalah hubungan normatif antara individu dan nilai (Sagala, 2012: 1).Peneliti melakukan studi pendahuluan yang dilaksanakan pada hari senin tanggal 15 Maret 2015 di SMP Negeri 2 Maba. Siswa yang mengikuti tes sebanyak 23 orang, berdasarkan hasil kerja siswa ternyata masih banyak yang belum bisa mengerjakan soal dengan baik, sebagian besar siswa memperoleh nilai yang tidak memuaskan, artinya dalam mengerjakan soal siswa lebih banyak memperoleh nilai salah dibandingkan nilai benar. dari hasil tes yang diperoleh hanya dua siswa yang mampu 
menyelesaikan soal, namun belum bisa dikatakan maksimal karena penyelesaian yang mereka lakukan tidak sesuai dengan prosedur penyelesaian. Kebanyakan siswa yang mendapatkan nilai dibawah rata-rata mengalami kesulitan pada soal nomor 4 dengan menggunakan indikator aspek kemampuan pemecahan masalah matematis, ini menunjukkan bahwa kemampuan pemecahan masalah matematis siswa masih rendah dilihat dari soal yang diberikan.Berikut contoh hasil kerja dari salah satu siswa.

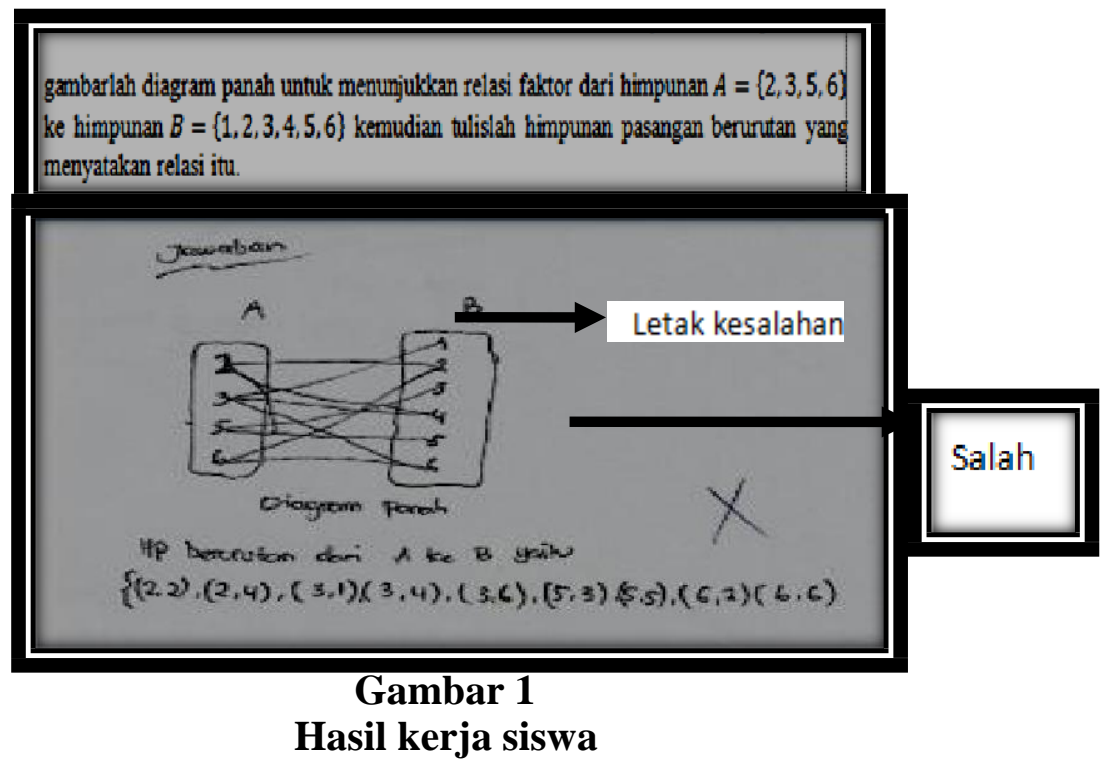

Dari gambar di atas menunjukkan bahwa siswa belum bisa menyelesaikan soal dengan baik, cara membuat diagram panah maupun menulis pasangan berurutan dari relasi tersebut belum tepat. Pada gambar 1 menunjukkan bahwa letak keselahan siswa dalam membuat diagram panah pada himpunan A ke himpunan B yaitu faktor dari 3 yaitu 4 dan faktor dari 5 yaitu 3, dan letak kesalahan siswa dalam menulis pasangan berurutan yaitu $(3,4),(5,3)$. Dari hasil kerja siswa di atas menunjukkan bahwa siswa belum memahami strategi penyelesaian, dan juga siswa belum memahami materi yang diajarkan.Oleh karena itu, diperlukan model pembelajaran yang dapat membantu siswa dalam memahami materi, serta memotivasi siswa agar lebih aktif dalam proses belajar mengajar. Salah satu model pembelajaran yang dikatakan sangat efektif dalam membantu siswa memahami materi adalah dengan menerapkan model PBM. Model PBM dapat mengembangkan kemampuan siswa dalam belajar. Pembelajaran dimulai dengan pemberian masalah, masalah yang dimiliki adalah masalah konteks dengan dunia nyata.Siswa secara berkelompok aktif merumuskan masalah mempelajari dan mencari sendiri materi yang terkait dengan masalah dan melaporkan solusi dari masalah.Ibrahim \& Nur (Nurdalilah, dkk, 2008: 112) menjelaskan bahwa manfaat model pembelajaran berbasis masalah adalah membantu siswa mengembangkan kemampuan berfikir tingkat tinggi, memecahkan masalah, belajar berperan 
sebagai orang dewasa melalui keterlibatan mereka dalam pengalaman nyata dan simulasi menjadi pembelajar yang otonom dan mandiri.

\section{METODE PENELITIAN}

Penelitian ini dilaksanakan di kelas VIII ${ }^{1}$ dan kelas VIII ${ }^{2}$ SMP Negeri 2 Maba yang dilaksanakan pada semester genap tahun ajaran 2015/2016 dengan materi relasi. Jenis penelitian yang digunakan dalam penelitian ini adalah jenis penelitian eksperimen tipe pretest-posttest control group design, Sugiyono (2014: 79).Desain penelitiannya dapat digambarkan sebagai berikut:

\section{Tabel 2 Desain}

penelitian

\begin{tabular}{|l|l|l|}
\hline$O_{1}$ & $X_{1}$ & $O_{2}$ \\
\hline$O_{1}$ & $X_{2}$ & $O_{2}$ \\
\hline
\end{tabular}

Keterangan:

$O_{1}=$ Pretest pada kelas PBM dan Konvensional

$\mathrm{O}_{2}=$ Posttest pada kelas PBM dan Konvensional

$X_{1}=$ kelas yang diajarkan dengan model pembelajaran berbasis masalah (PBM).

$X_{2}=$ kelas yang diajarkan dengan pembelajaran konvensional.

Populasi dalam penelitian ini adalah seluruh siswa kelas VIII SMP Negeri 2 Maba yang berjumlah 60 siswa. Sampel adalah bagian dari jumlah dan karakteristik yang dimiliki oleh populasi tersebut. Sampel yang digunakan untuk penelitian ini adalah siswa kelas VIII ${ }^{1}$ dan VIII $^{2}$ yang berjumlah 60 siswa yang tersebar dalam dua kelas. Variabel dalam penelitian ini yaitu variabel bebas (X) dan variabel terikat (Y). Teknik pengumpulan data dalam penelitian ini diperoleh dengan cara melakukan observasi memberikan pre-test, memberikan perlakuan pada kelas yang menjadi subjek penelitiandan memberikan post-test, menganalisis data. Untuk mengetahui kemampuan pemecahan masalah matematis siswa melalui model pembelajaran berbasis masalah dalam penelitian ini adalah dengan menggunakan analisis deskriptif, bagaimana kemampuan pemecahan masalah matematis siswa melalui model pembelajaran berbasis masalah dianalisis dengan penskoran per indikator dan keseluruhan. Data kemampuan pemecahan masalah matematis digolongkan berdasarkan penilaian kualifikasi kemampuan pemecahan masalah matematis siswa menurut Mawaddah \& Anisah (2015: 170) sebagai berikut: 
Tabel 3

Kualifikasi Kemampuan Pemecahan Masalah

Matematis Siswa

\begin{tabular}{|c|c|}
\hline Nilai & Kualifikasi \\
\hline $85,00-100$ & Sangat Baik \\
\hline $70,00-84,99$ & Baik \\
\hline $55,00-69,99$ & Cukup \\
\hline $40,00-54,99$ & Kurang \\
\hline $0-39,99$ & Sangat Kurang \\
\hline
\end{tabular}

Analisis Inferensial

1) Uji Prasyarat Analisis

Sebelum pengujian hipotesis dilakukan, terlebih dahulu akan dilakukan uji normalitas dan uji homogenitas. Uji normalitas bertujuanuntuk mengetahui apakah data berasal dari populasi yang berdistribusi normal atau tidak. Hipotesis yang diajukan:

$\mathrm{H}_{0}$ : Data berasal dari populasi yang berdistribusi normal

$\mathrm{H}_{1}$ : Data berasal dari populasi yang tidak berdistribusi normal Analisis data yang digunakan adalah uji Chi-Kuadrat, dengan rumus: 


$$
\begin{aligned}
&\left(\chi^{2}\right)= \sum_{\mathrm{i}=1}^{\mathrm{k}} \frac{(\mathrm{fo}-\mathrm{fe})^{2}}{\mathrm{fe}} \\
& \text { Keterangan: } \\
& \\
& \chi^{2}=\text { Chi kuadrat } \\
& f_{o}=\text { Frekuensi yang diamati } \\
& f_{e}=\text { Frekuensi yang diharapkan }
\end{aligned}
$$

Dengan kriteria: Jika $\chi_{\text {hit }}^{2}>\chi_{\text {tab }}^{2}$ data tidak normal

Jika $\chi_{\text {hit }}^{2}<\chi_{\text {tab }}^{2}$ data normal(Sugiyono, 2007: 77-82).

Uji homogenitasbertujuan untuk mengetahui apakah kedua kelas tersebut mempunyai varian yang sama atau tidak. Jika kedua kelas mempunyai varian yang sama maka kelas tersebut dikatakan homogen.Hipotesis yang diajukan:

$H_{0}: \sigma_{1}{ }^{2}=\sigma_{2}{ }^{2}$,artinya kedua kelompok sampel mempunyai varians yang sama.

$H_{1}: \sigma_{1}^{2} \neq \sigma_{2}{ }^{2}$, artinya kedua kelompok sampel mempunyai varians tidak sama.

Uji Hipotesis,berdasarkan hasil analisis data menunjukkan bahwa data berdistribusi normal dan homogen, maka digunakan statistik uji parametrik yangdigunakan adalah uji-t(Sugiyono, 2007: 138), yakni sebagai berikut:

$$
t_{\text {hitung }}=\frac{\overline{\mathrm{X}}_{1}-\overline{\mathrm{X}}_{2}}{\frac{\mathrm{n}_{1-1) S^{2}+\left(n_{2}-1\right) S^{2}}}{n_{1+n_{2}-2}} \frac{1}{\bar{n}_{1}}+\frac{1}{n_{2}}}
$$

Hipotesis statistik yang diajukan dalam penelitian ini adalah sebagai berikut:

$$
\begin{aligned}
& H_{0}: \mu_{1}=\mu_{2} \\
& H_{1}: \mu_{1} \neq \mu_{2}
\end{aligned}
$$

Keterangan:

$\mathrm{H}_{0}$ : Tidak terdapat perbedaan kemampuan pemecahan masalah matematis siswa melalui model pembelajaran berbasis masalah dengan pembelajaran konvesional.

$\mathrm{H}_{1}$ : terdapat perbedaan kemampuan pemecahan masalah matematis siswa melalui model pembelajaran berbasis masalah dengan pembelajaran konvesiona

\section{HASIL DAN PEMBAHASAN}

\section{HASIL}

\section{KemampuanPemecahanMasalahMatematis Siswa MelaluiModel PBM}

Kemampuan pemecahan masalah matematis siswa melalui model pembelajaran berbasis masalah setelah dianalisis dengan penskoran per indikator dan keseluruhan, dengan menggunakan kualifikasi kemampuan pemecahan masalah matematis dengan jumlah 20 siswa diperoleh data sebagai berikut:

a. Kemampuan memahami masalah atau mengidentifikasi unsur-unsur yang diketahui dan ditanyakan. 
Data hasil kerja siswa setelah diterapkan model pembelajaran berbasis masalah, berdasarkan analisis data dengan menggunakan kualifikasi kemampuan pemecahan masalah matematis siswa diperoleh kualifikasi sangat baik, baik, cukup dan kurang.

\section{Tabel 4}

Data hasil kualifikasi indikator memahami masalah atau mengidentifikasi unsur-unsur yang diketahui dan ditanyakan.

\begin{tabular}{|c|c|c|c|}
\hline Nilai & Kualifikasi & Frekuensi & Persentasi \\
\hline $85,00-100$ & Sangat Baik & 5 & $25 \%$ \\
\hline $70,00-84,99$ & Baik & 11 & $55 \%$ \\
\hline $55,00-69,99$ & Cukup & 2 & $10 \%$ \\
\hline $40,00-54,99$ & Kurang & 2 & $10 \%$ \\
\hline $0-39,99$ & Sangat Kurang & 0 & $0 \%$ \\
\hline Jumlah & & $\mathbf{2 0}$ & $\mathbf{1 0 0 \%}$ \\
\hline
\end{tabular}

Data yang disajikan pada tabel di atas menunjukkan bahwa hasil posttest siswa untuk kualifikasi sangat baik sebanyak 5 siswa dengan persentasi sebesar 25\%, kualifikasi baik sebanyak 11 siswa dengan persentasi sebesar 55\%, kualifikasi cukup sebanyak 2 siswa dengan persentasi sebesar 10\%, dan kualifikasi kurang sebanyak 2 siswa dengan persentasi sebesar $10 \%$.

b. Kemampuan menyusun model matematika dari masalah nyata

Data hasil kerja siswa setelah diterapkan model pembelajaran berbasis masalah, berdasarkan analisis data dengan menggunakan kualifikasi kemampuan pemecahan masalah matematis siswa diperoleh kualifikasi sangat baik, baik, cukup dan sangat kurang.

\section{Tabel 5}

Data hasil kualifikasi indikator menyusun model matematika dari masalah nyata.

\begin{tabular}{|c|c|c|c|}
\hline Nilai & Kualifikasi & Frekuensi & Persentasi \\
\hline $85,00-100$ & Sangat Baik & 8 & $40 \%$ \\
\hline $70,00-84,99$ & Baik & 6 & $30 \%$ \\
\hline $55,00-69,99$ & Cukup & 4 & $20 \%$ \\
\hline $40,00-54,99$ & Kurang & 0 & $0 \%$ \\
\hline $0-39,99$ & Sangat Kurang & 2 & $10 \%$ \\
\hline Jumlah & & $\mathbf{2 0}$ & $\mathbf{1 0 0 \%}$ \\
\hline
\end{tabular}

Data yang disajikan pada tabel di atas menunjukkan bahwa hasil posttest siswa untuk kualifikasi sangat baik sebanyak 8 siswa dengan persentasi sebesar 40\%, kualifikasi baik sebanyak 6 siswa dengan persentasi sebesar 30\%, kualifikasi cukup sebanyak 4 siswa dengan persentasi sebesar 20\%, dan kualifikasi sangat kurang sebanyak 2 siswa dengan persentasi sebesar $10 \%$. 
c. Kemampuan menyelesaikan berbagai macam strategi yang cocok untuk memecahkan masalah

Data hasil kerja siswa setelah diterapkan model pembelajaran berbasis masalah, berdasarkan analisis data dengan menggunakan kualifikasi kemampuan pemecahan masalah matematis siswa diperoleh kualifikasi sangat baik, cukup dan sangat kurang.

Tabel 6

Data hasil kualifikasi indikator menerapkan strategi untuk memecahkan masalah.

\begin{tabular}{|c|c|c|c|}
\hline Nilai & Kualifikasi & Frekuensi & Persentasi \\
\hline $85,00-100$ & Sangat Baik & 15 & $75 \%$ \\
\hline $70,00-84,99$ & Baik & 0 & $0 \%$ \\
\hline $55,00-69,99$ & Cukup & 3 & $15 \%$ \\
\hline $40,00-54,99$ & Kurang & 0 & $0 \%$ \\
\hline $0-39,99$ & Sangat Kurang & 2 & $10 \%$ \\
\hline Jumlah & & $\mathbf{2 0}$ & $\mathbf{1 0 0 \%}$ \\
\hline
\end{tabular}

Data yang disajikan pada tabel di atas menunjukkan bahwa hasil posttest siswa untuk kualifikasi sangat baik sebanyak 15 siswa dengan persentasi sebesar 75\%, kualifikasi cukup sebanyak 3 siswa dengan persentasi sebesar $15 \%$, dan kualifikasi sangat kurang sebanyak 2 siswa dengan persentasi sebesar $10 \%$.

Dari hasil kualifikasi dan persentasi data di atas berdasarkan setiap indikator, berikut akan ditunjukkan hasil kualifikasi dan persentasi kemampuan pemecahan masalah matematis siswa secara keseluruhan berdasarkan analisis kualifikasi kemampuan pemecahan masalah matematis siswa.

Tabel 7

Data hasil kualifikasi dan persentasi siswa secara keseluruhan

\begin{tabular}{|c|c|c|c|}
\hline Nilai & Kualifikasi & Frekuensi & Persentasi \\
\hline $85,00-100$ & Sangat Baik & 14 & $55 \%$ \\
\hline $70,00-84,99$ & Baik & 3 & $30 \%$ \\
\hline $55,00-69,99$ & Cukup & 2 & $10 \%$ \\
\hline $40,00-54,99$ & Kurang & 1 & $5 \%$ \\
\hline $0-39,99$ & Sangat Kurang & 0 & $0 \%$ \\
\hline Jumlah & & $\mathbf{2 0}$ & $\mathbf{1 0 0 \%}$ \\
\hline
\end{tabular}

Data yang disajikan pada tabel di atas menunjukkan bahwa hasil posttest siswa untuk kualifikasi sangat baik sebanyak 14 siswa dengan persentasi sebesar 55\%, kualifikasi baik sebanyak 3 siswa dengan persentasi sebesar 
$30 \%$, kualifikasi cukup sebanyak 2 siswa dengan persentasi sebesar $10 \%$, dan kualifikasi kurang sebanyak 1 siswa dengan persentasi sebesar5\%.Deskripsi data tersebut akan diperlihatkan dalam diagram batang berikut ini.

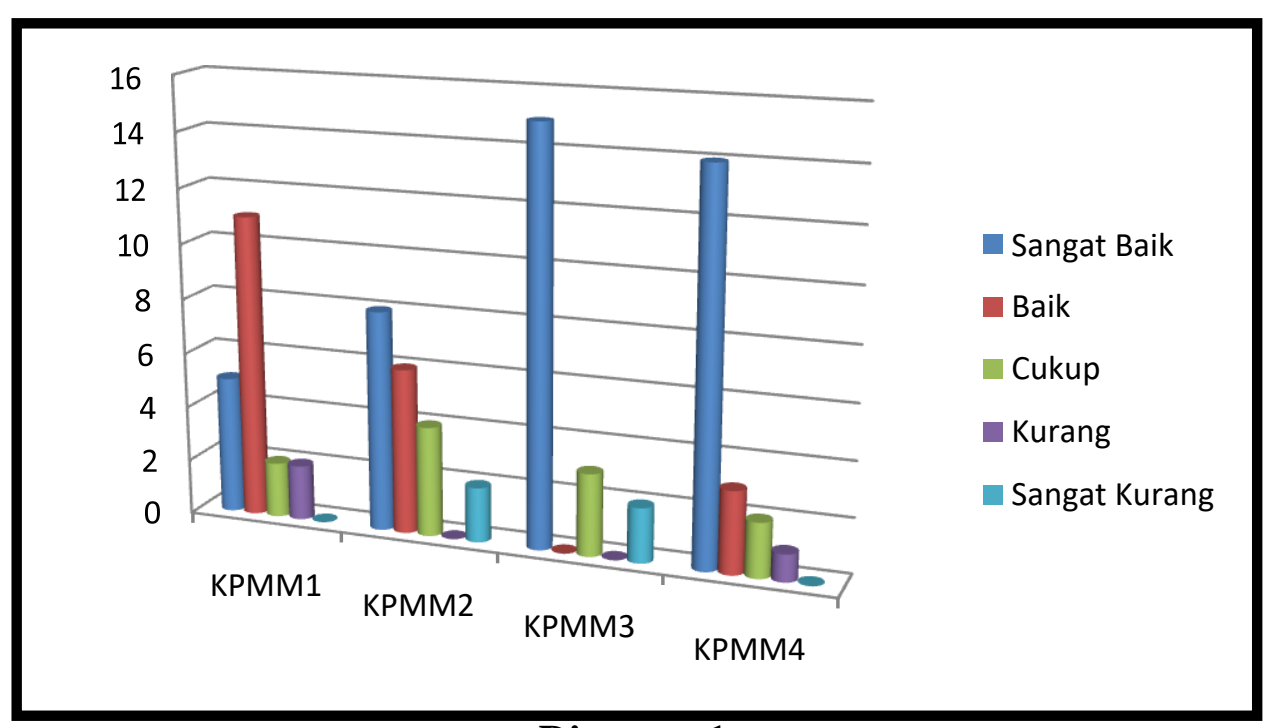

\section{Diagram 1}

Keterangan:

Data hasil kualifikasi siswa secara keseluruhan

$\mathrm{KPMM}_{1}$ : Memahami masalah(mengidentifikasi unsur-unsur yang diketahui dan ditanyakan).

$\mathrm{KPMM}_{2}$ : Menyusun model matematika dari masalah nyata.

$\mathrm{KPMM}_{3}$ : Menerapkan strategi untuk memecahkan masalah

$\mathrm{KPMM}_{4}$ : Kemampuan pemecahan masalah matematis siswa secara keseluruhan

\section{Pengujian Persyaratan Analisis}

Data yang digunakan pada analisis statistik inferensial ini adalah data yang diperoleh dari kedua kelassetelah perlakuan. Data setelah perlakuan digunakan untuk melakukan pengujian hipotesis, yaitu mengetahui terdapat atau tidak perbedaan kemampuan pemecahan masalah matematis siswa melalui model PBM dengan pembelajaran konvensional. Pengujian persyaratan analisis data yakni uji normalitas dan homogenitas.

\section{Uji Normalitas}

\section{Tabel 8}

Hasil uji normalitas kelas eksperimen dan kelas kontrol

\begin{tabular}{|c|c|c|c|c|c|}
\hline \multicolumn{3}{|c|}{ Kelas eksperimen } & \multicolumn{3}{c|}{ Kelas control } \\
\hline$x_{\text {hitung }}^{2}$ & $x_{\text {tabel }}^{2}$ & kesimpulan & $x_{\text {hitung }}^{2}$ & $x_{\text {tabel }}^{2}$ & Kesimpulan \\
\hline 10,21 & 11,070 & Normal & 9,71 & 14,017 & Normal \\
\hline
\end{tabular}

Hasil uji normalitas data untukkelas eksperimen dengan rumus chi-

kuadarat diperoleh nilai $x_{\text {hitung }}^{2}=10,21$ dan $x_{\text {tabel }}^{2}=11,070$ karena $x_{\text {hitung }}^{2}$ $x^{2}$ tabel maka kesimpulan data berdistribusi normal, Sedangkan pada kelas kontrol 
diperoleh nilai $x_{\text {hitung }}^{2}=9,71$ dan $x_{\text {tabel }}^{2}=14,017$ karena $X_{\text {hitung }}^{2} \leq X_{\text {tabel }}^{2}$ maka kesimpulannya data berdistribusi normal.

\section{Uji Homogenitas}

\section{Tabel 9}

Hasil uji homogenitas

\begin{tabular}{|c|c|c|}
\hline \multicolumn{3}{|c|}{ Uji homogenitas kelas eksperimen dan kelas control } \\
\hline $\mathrm{F}_{\text {hit }}$ & $\mathrm{F}_{\text {tab }}$ & Keterangan \\
\hline 1,46 & 2,07 & homogen \\
\hline
\end{tabular}

Hasil uji homogenitas dari kedua data bersifat homogen dengan nilai $F_{\text {hitung }} \leq \mathrm{F}_{\text {tabel }}$ atau $1,46 \leq 2,07$.

\section{Pengujian Hipotesis}

Berdasarkan uji chi kuadrat menunjukan bahwa data tentang hasil tes kemampuan pemecahan masalah matematis siswa melalui model pembelajaran berbasis masalah dengan pembelajaran konvensional berdistribusi normal, dan homogen Sehingga statistik uji yang digunakan adalah statistik uji parametrik yakni uji- $t$

Tabel 10

Hasil uji hipotesis

\begin{tabular}{|c|c|c|}
\hline \multicolumn{3}{|c|}{ Uji hipotesis } \\
\hline$t_{\text {hit }}$ & $\mathrm{t}_{\text {tab }}$ & Kesimpulan \\
\hline 2,47 & 2,000 & $\mu_{1} \neq \mu_{2}$ \\
\hline
\end{tabular}

Hasil uji- $t$ untuk mengetahui perbedaan kemampuan pemecahan masalah matematis siswa melalui model pembelajaran berbasis masalah dengan pembelajaran konvensional diperoleh $t_{\text {hitung }}=2,47$ dengan $t_{\text {tabel }}=2,000$ maka $t_{\text {hitung }} \geq t_{\text {tabel }}$ atau $2,47 \geq 2,000$ pada derajat kebebasan 46 dan taraf signifikan $(\alpha)=0,05$. Maka $\mathrm{H}_{0}$ ditolak dan $\mathrm{H}_{1}$ diterima artinya terdapat perbedaan kemampuan pemecahan masalah matematis siswa melalui model pembelajaran berbasis masalah dengan pembelajaran konvensional.

\section{HASIL PENELITIAN}

\section{Kemampuan Pemecahan Masalah Matematis Siswa Melalui Model Pembelajaran Berbasis Masalah.}

Berdasarkan analisis data dan penyajian data di atas, diketahui bahwa terdapat perbedaan kemampuan pemecahan masalah matematis siswa melalui model pembelajaran berbasis masalah dengan pembelajaran konvensional. Pada saat penelitian, model pembelajaran berbasis masalah diterapkan di kelas VIII $^{1}$ sedangkan pembelajaran konvensional diterapkan di kelas VIII $^{2}$. Tujuan dalam penelitian ini adalah untuk mengetahui kemampuan pemecahan masalah matematis siswa melalui model pembelajaran berbasis masalah dan mengetahui 
apakah terdapat perbedaan kemampuan pemecahan masalah matematis siswa melalui model pembelajaran berbasis masalah dengan pembelajaran konvensional, berikut ini adalah interpretasi dari analisis hasil penelitian.

\section{Kemampuan Pemecahan Masalah Matematis Siswa Melalui Model Pembelajaran Berbasis Masalah.}

Berdasarkan analisis hasil penelitian, dapat diketahui pada kelas eksperimen bahwa hasil kualifikasi dan persentasi untuk indikator kemampuan memahami masalah atau mengidentifikasi unsur-unsur yang diketahui dan ditanyakan secara keseluruhan kualifikasi yang paling banyak yakni kualifikasi baik dengan persentasi sebesar 55\%.Berikut hasil kerja dari salah satu siswa dalam kemampuan memahami masalah atau mengidentifikasi unsur-unsur yang diketahui dan ditanyakan.

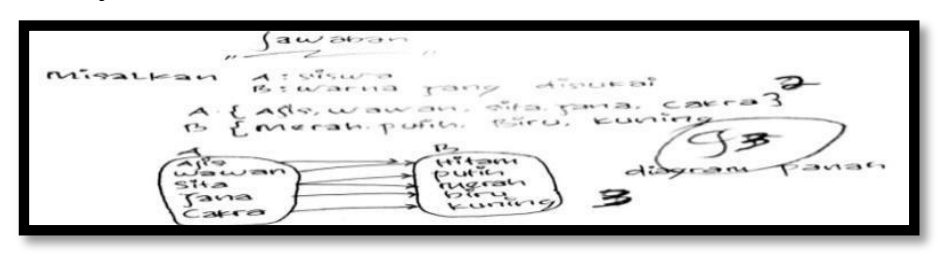

Gambar 2

\section{Hasil kerja siswa A9 dalam kemampuan memahami masalah atau} mengidentifikasi unsur-unsur yang diketahui dan ditanyakan.

Dari gambar di atas menunjukkan bahwa jawaban yang dibuat siswa masih terdapat kekurangan atau belum lengkap penyelesaiannya misalnya, pada indikator memahami (mengidentifikasi unsur-unsur yang diketahui dan ditanyakan). Pada gambar di atas jawaban yang dibuat siswa belum lengkap yaitu menyebutkan warna yang disukai siswa dan apa yang ditanyakan pada soal. Siswa hanya menuliskan warna merah, putih, biru dan kuning. Seharusnya warna yang disukai siswa terdiri dari warna hitam, putih, merah, biru, dan kuning. Dan siwa tidak menuliskan apa yang ditanyakan pada soal dengan indikator memahami masalah (mengidentifikasi unsur-unsur yang diketahui dan ditanyakan.

Indikator kemampuan menyusun model matematika dari masalah nyata diperoleh secara keseluruhan kualifikasi yang paling banyak yakni kualifikasi sangat baik dengan persentasi sebesar $40 \%$.Berikut hasil kerja siswa dalam kemampuan menyusun model matematika dari masalah nyata.

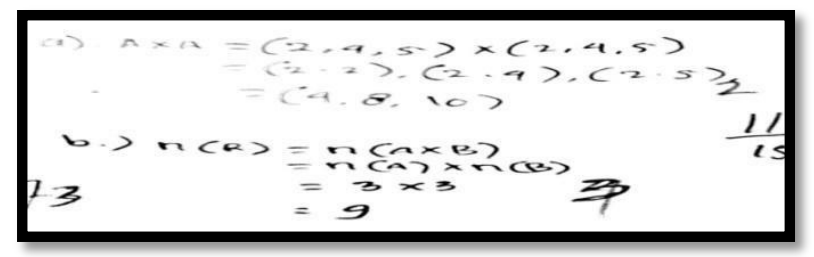

Gambar 3

Hasil kerja siswa A12 dalam kemampuan menyusun model matematika dari masalah nyata 
Dari gambar di atas terlihat bahwa penyelesaian yang buat siswa tidak sesuai dengan yang diharapkan pemberian skor 2 pada soal 2.a disebabkan karena penyelesaian yang dibuat siswa belum lengkap, siswa hanya menuliskan $\mathrm{A} \times \mathrm{A}=$ $(2,4,5) \times(2,4,5)=(2.2),(2.4),(2.5)=(4,8,10)$ penyelesaian yang dibuat siswa masih terdapat kekurangan. Jawaban yang seharusnya: $\mathrm{A} \times \mathrm{A}=(2,4,5) \mathrm{x}(2,4,5)$ $=\{(2.2),(2.4),(2.5),(4.2),(4.4),(4.5),(5.2),(5.4),(5.5)\}=\{(4,8,10),(8,16,20)$, $(10,20,25)\}$. Pada soal 2.b,nampak bahwa penyelesaian siswa dalam membuat model matematika dikerjakan dengan benar dan tidak ada kesalahansesuai dengan prosedur yang diinginkan.

Indikator menyelesaikan berbagai macam strategi yang cocok untuk memecahkan masalah diperoleh secara keseluruhan kualifikasi yang paling banyak yakni kualifikasi sangat baik dengan persentasi sebesar 75\%. Berikut hasil kerja siswa dalam kemampuan menyelesaikan berbagai macam strategi yang cocok untuk memecahkan masalah

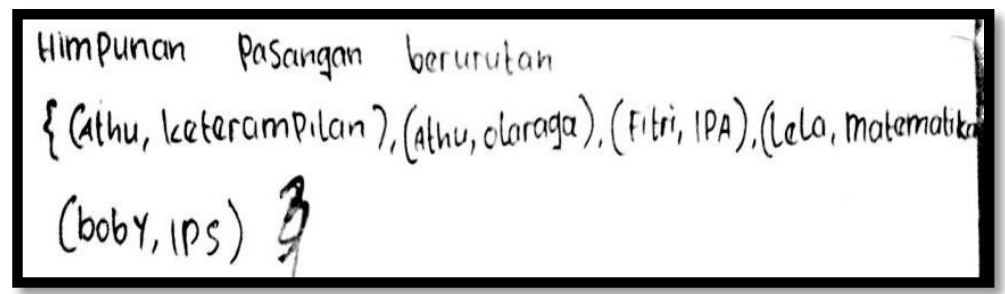

\section{Gambar 4}

Hasil kerja siswa A5 dalam kemampuan menerapkan strategi untuk memecahkan masalah

Berdasarkan hasil kerja di atas dapat diketahui bahwa siswa tersebut mampu menyelesaikan masalah dengan kemampuan menyelesaikan berbagai macam strategi yang cocok untuk memecahkan masalah dijawab dengan benar dan tidak ada kesalahan sesuai dengan prosedur yang diinginkan.

3. Perbedaan Kemampuan pemecahan masalah matematis melalui model PBM dengan pembelajaran konvensional.

Perbedaan kamampuan pemecahan masalah matematis siswa melalui modelPBMdengan pembelajaran konvensional dapat dilihat dengan membandingkan hasil kerja siswa setelah pelaksanaan posttest.Membandingkan hasil kerja siswa dengan melihat kemampuan yang telahatau belum dicapai oleh siswa. Hasil kerja siswa tersebut dapat dilihat di bawah ini:

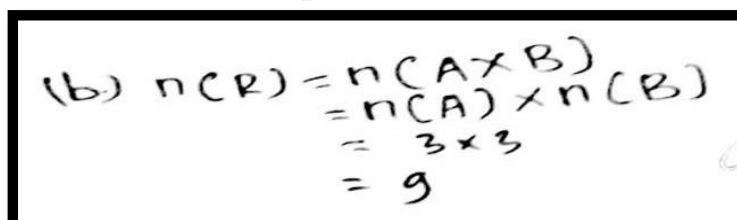

Gambar 5

Hasil kerja siswa A16melalui model pembelajaran berbasis masalah 
Gambar di atas merupakan hasil kerja siswa melalui model PBM pada kemampuan menyusun model matematika dari masalah nyata. Pada hasil kerja siswa di atas menunjukkan bahwa siswa sudah mampu menyelesaikan model matematika dengan baik tanpa ada kesalahan dan mampu menyelesaikan soal sesuai dengan prosedur yang diinginkan.

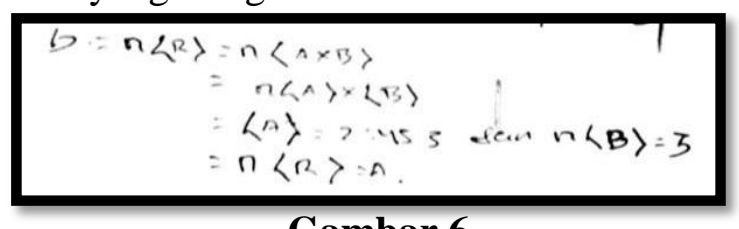

\section{Gambar 6}

Hasil kerja siswa $\mathrm{B8}$ melalui pembelajaran konvensional

Gambar 6 merupakan hasil kerja siswa melalui pembelajaran konvensional pada kemampuan menyusun model matematika dari masalah nyata. Hasil kerja siswa di atas menunjukkan bahwa siswa sudah mampu menuliskan model matematika namun masih terdapat kesalahan dalam menyelesaikan soal tersebut. Kesalahan yang dibuat siswa disebabkan karena siswa belum memahami langkahlangkah penyelesaian sehingga siswa tidak bisa menentukan jumlah anggota dari himpunan A dan himpunan B.

Hasil kerja siswa tersebut menunjukkan bahwa terdapat perbedaan kemampuan pemecahan masalah matematis siswa melalui model pembelajaran berbasis masalahdenganpembelajaran konvensional.Perbedaannya yakni hasil kerja siswa melalui model pembelajaran berbasis masalah, siswa mampu menyelesaikan soal dengan kemampuan menyusun model matematika dari masalah nyata dengan baik tanpa ada kesalahan.Hasil kerja siswa pada pembelajaran konvensional, siswa belum mampu menyelesaikan soal dengan kemampuan menggunakan model matematika dari masalah nyata, disebabkan karena siswa belum memahami langkah-langkah penyelesaian dari soal tersebut oleh karena itu siswa belum bisa menuliskan berapa banyak jumlah anggota dari himpunan A dan himpunan B.

\section{KESIMPULAN}

Berdasarkan hasil analisis data dan pembahasan di atas, maka dapat disimpulkan bahwakemampuan pemecahan masalah matematis siswa kelas VIII $_{1}$ pada materi relasi di SMP Negeri 2 Mabamelalui model pembelajaran berbasis masalahberkualifikasi sangat baik, baik, cukup dan kurang. Terdapat perbedaan kemampuan pemecahan masalah matematis siswa kelas VIII SMP Negeri 2 Maba pada materi relasi melalui model pembelajaran berbasis masalahdengan pembelajaran konvensional. 


\section{DAFTAR PUSTAKA}

Harsono dkk., 2009. Perbedaan Hasil Belajar Antara Metode Ceramah Konvensional dengan Ceramah Berbantuan Media Animasi pada Pembelajaran Kompetensi Perakitan dan Pemasangan Sistem Rem. Jurnal PTM. Vol. 9, No. 2. Hal: 74.

Mawaddah dan Anisah., 2015. Kemampuan Pemecahan Masalah Matematis Siswa pada Pembelajaran Matematika dengan Menggunakan Model Pembelajaran Generatif (Generative Learning) di SMP. Jurnal Pendidikan Matematika. Vol. 3, No. 2. Hal: 170.

Nurdalilah dkk., 2008. Perbedaan Kemampuan Penalaran Matematika dan pemecahan masalah pada Pembelajaran Berbasis Masalah dan Pembelajaran Konvensional di SMA Negeri 1 Kualuh Selatan. Jurnal Pendidikan Matematika PARADIKMA. Vol. 6, No. 2. Hal: 109-119.

Noer. 2009. Peningkatan Kemampuan Berpikir Kritis Matematis Siswa SMP melalui pembelajaran Berbasis Masalah. Prosiding Seminar Nasional Matematika dan Pendidikan Matematika Jurusan Pendidikan Matematika FMIPA UNY 5 Desember 2009. Lampung

Rusman. 2012. Model-Model Pembelajaran Mengembangkan Profesionalisme Guru. Jakarta: PT Raja Grafindo Persada.

Sagala. 2012. Konsep dan Makna Pembelajaran. Bandung: Alvabeta.

Sugiyono. 2014. Metode Penelitian Kuantitatif Kualitatif dan R\&D. Bandung: Alfabeta.

Sunaryo. 2014. Model Pembelajaran Berbasis Masalah Untuk Meningkatkan Kemampuan Berpikir Kritis dan Kreatif Matematik Siswa SMA di Kota Tasikmalaya. Jurnal Pendidikan dan Keguruan. Vol. 1, No. 2. Hal: 41-51.

Widjajanti. 2009. Kemampuan Pemecahan Masalah Matematis Mahasiswa Calon Guru Matematika Apa dan Bagaimana Mengembangkannya. ProsidingSeminar Nasional Matematika dan Pendidikan Matematika Jurusan Pendidikan MatematikaFMIPA UNY Desember 2009. Yogyakarta. 